\title{
FAKTOR-FAKTOR YANG MEMPENGARUHI PENDAPATAN UMKM PADA MASA PANDEMI COVID-19
}

\author{
Dedi Damhudi 1), Tri Lestari ${ }^{2)}$, Faizal Roni ${ }^{3)}$ \\ 1) Universitas Darma Persada \\ ${ }^{2)}$ Universitas Bina Sarana Informatika \\ ${ }^{3)}$ Universitas Bina Sarana Informatika \\ 1'dedi_damhudi@fe.unsada.ac.id , ${ }^{2}$ tri.tle@ bsi.ac.id' ${ }^{3}$ faizal.fzi@bsi.ac.id
}

\begin{abstract}
During the pandemic of COVID-19, many businesses have been falling and have a declining revenue. By gathering information samplings through online surveys consisted of thirty-two respondents and the usage of Chi-square quantitative analysis data method, the study was conducted by finding out its effect on income during the pandemic. The independent variables consisted of business income before the pandemic, the loans, and the BPUM used to see the correlation with the dependent variable. The findings show that the independent variables had a statistically significant influence on the dependent variable in parallel.
\end{abstract}

Keywords: Income during pandemic, loans, BPUM, COVID-19

\section{PENDAHULUAN}

Pandemi COVID-19 ditandai dengan awal munculnya virus Corona COVID-19 (SARS-CoV-2) di Wuhan, China pada bulan Desember 2019. Sedangkan di Indonesia, menurut (Pranita, 2020) virus Corona COVID-19 masuk ke Indonesia berdasarkan pengumuman pemerintah pada tanggal 2 Maret 2020 dengan ditemukannya dua kasus pasien positif COVID-19 yang pertama kali terjadi di daerah Depok, Jawa Barat. Kendati demikian menurut (Alam, 2020) banyak ahli yang berpendapat bahwa kemungkinan besar virus Corona COVID-19 telah masuk ke Indonesia pada bulan Januari 2020 dengan melihat mobilitas dari penduduk. Terlepas dari kapan pertama kali virus Corona COVID-19 masuk ke Indonesia, dampak dari virus Corona COVID-19 telah membuat perekonomian runtuh, tidak hanya di Indonesia, namun juga di seluruh negara. Kebijakan mengunci akses masuk dan akses keluar suatu negara diseluruh dunia, berlaku tidak hanya bagi manusia, namun juga berlaku untuk barang, termasuk produk bahan mentah dan produk jadi, hal ini tentu saja menyebabkan sirkulasi ekspor dan impor terganggu. Bagi produk yang diproses masih mengandalkan bahan mentah yang berasal dari negara lain, maka secara otomatis menjadi tersendat dalam melakukan proses produksi. Begitu juga dengan perdagangan yang menjual produk-produk berupa produk jadi yang langsung dijual, tidak memerlukan proses produksi dan berasal dari luar negeri, produk-produk tersebut menjadi hilang di pasaran dan mejadi sangat sulit ditemukan. Kebijakan pemerintah Indonesia sendiri yang menerapkan PSBB (Pembatasan Sosial Berskala Besar) pada sejumlah daerah, dan terakhir Indonesia melakukan penerapan PSBB Jawa Bali memberikan dampak negatif terhadap pertumbuhan ekonomi Indonesia, khususnya pertumbuhan Usaha Mikro Kecil Menengah. Hal tersebut berdasarkan permyataan Menteri 
Keuangan Republik Indonesia Ibu Sri Mulyani Indrawati, bahwa PSBB menyebabkan kegiatan perekonomian di Indonesia terkontraksi sampai dengan 5,32\% (S. Lidya Julita, 2020).

Dampak dari COVID-19 terhadap UMKM dipandang perlu untuk dilakukan penelitian, karena Usaha Mikro Kecil Menengah (UMKM) merupakan salah satu motor penggerak bagi perekonomian di Indonesia, peran UMKM sangatlah besar dalam menurunkan tingkat pengangguran di Indonesia. UMKM memberikan kontribusi besar terhadap roda perekenomian di Indonesia. Berdasarkan data dari Kementerian Koperasi dan Usaha Kecil dan Menengah Republik Indonesia pada tahun 2018 (Kemenkop UKM RI, 2020) (sampai dengan saat penelitian dilakukan, data terbaru yang diterbitkan oleh Kementerian Koperasi dan Usaha Kecil dan Menengah adalah data tahun 2018), UMKM memberikan kontribusi 99.9\% terhadap unit usaha di Indonesia yaitu sebanyak 64.194.057 unit usaha dibandingkan dengan unit usaha besar yang hanya sebesar $1 \%$ atau sebanyak 5.550 unit usaha. UMKM memberikan 97\% kontribusi terhadap tenaga kerja yaitu sebanyak 116.978.631 orang, dan memberikan kontribusi terhadap Produk Domestik Bruto (PDB) atas dasar harga berlaku $61.07 \%$ atau sebesar Rp. 8.573.895,3 milyar. Dengan kontribusi yang begitu besar, UMKM perlu dijaga agar tetap stabil dan memiliki kemampuan untuk dapat melanjutkan usahanya ditengah pandemi COVID-19 saat ini.

Menurut data yang dihimpun oleh (BPS, 2020b), pertumbuhan perekonomian Indonesia pada tahun 2020 saat pandemi COVID-19 terjadi, turun sebesar $2.07 \%$, jauh jika dibandingkan dengan tahun sebelumnya yaitu tahun 2019 (BPS, 2020a) yang mengalami peningkatan sebesar $5.02 \%$ dari tahun 2018. Kebijakan Internasional yang diterapkan hampir diseluruh negara, yaitu mengunci akses keluar dan akses masuk bagi manusia dan barang, menyebabkan bahan baku produksi menjadi langka, dan kebijakan pemerintah Indonesia sendiri yang menerapkan PSBB (Pembatasan Sosial Berskala Besar), di antaranya adalah kewajiban menjaga jarak, membuat pelaku UMKM terpaksa menurunkan tingkat produksi. Tidak hanya itu, setelah dengan terpaksa menurunkan tingkat produksi, pelaku UMKM juga harus menghadapi kenyataan adanya penurunan tingkat daya beli masyarakat yang lebih banyak melakukan kegiatan di rumah.

\section{LANDASAN TEORI}

\section{Usaha Mikro, Kecil dan Menengah}

Usaha mikro, kecil dan menengah mempunyai pengertian khusus yang sesuai dengan pengertian yang tercantum dalam (OJK, 2008) Undang-Undang nomor 20 tahun 2008 pasal satu ayat satu, dua, dan tiga sebagai berikut: 1) Usaha Mikro adalah usaha produktif milik orang perorangan dan/atau badan usaha perorangan yang memenuhi kriteria Usaha Mikro sebagaimana diatur dalam Undang-Undang ini. 2) Usaha Kecil adalah usaha ekonomi produktif yang berdiri sendiri, yang dilakukan oleh orang perorangan atau badan usaha yang bukan merupakan anak perusahaan atau bukan cabang perusahaan yang dimiliki, dikuasai, atau menjadi bagian baik langsung maupun tidak langsung dari Usaha Menengah atau Usaha Besar yang memenuhi kriteria Usaha Kecil sebagaimana dimaksud dalam UndangUndang ini. 3) Usaha Menengah adalah usaha ekonomi produktif yang berdiri sendiri, yang dilakukan oleh orang perorangan atau badan usaha yang bukan merupakan anak perusahaan atau cabang perusahaan yang dimiliki, dikuasai, atau menjadi bagian baik langsung maupun tidak langsung dengan Usaha Kecil atau 
Usaha Besar dengan jumlah kekayaan bersih atau hasil penjualan tahunan sebagaimana diatur dalam UndangUndang ini”.

Sedangkan klasifikasi dari usaha mikro, kecil, menengah di kelompokkan berdasarkan kekayaan bersih dan pendapatan penjualan seperti tercantum pada Undang-Undang yang sama yaitu Undang-Undang no. 20 tahun 2008 pada pasal enam ayat satu, dua dan tiga (OJK, 2008) adalah sebagai berikut: 1) Kriteria Usaha Mikro adalah sebagai berikut: a). Memiliki kekayaan bersih paling banyak 50 juta rupiah tidak termasuk tanah dan bangunan tempat usaha; atau b). Memiliki hasil penjualan tahunan paling banyak 300 juta rupiah. 2) Kriteria Usaha Kecil adalah sebagai berikut: a). Memiliki kekayaan bersih lebih dari 50 juta rupiah sampai dengan paling banyak 500 juta rupiah tidak termasuk tanah dan bangunan tempat usaha; atau b). Memiliki hasil penjualan tahunan lebih dari 300 juta rupiah sampai dengan paling banyak 2.5 milyar rupiah. 3) Kriteria Usaha Menengah adalah sebagai berikut: a). a. Memiliki kekayaan bersih lebih dari 500 juta rupiah sampai dengan paling banyak 10 milyar rupiah tidak termasuk tanah dan bangunan tempat usaha; atau b). b. Memiliki hasil penjualan tahunan lebih dari 2.5 milyar rupiah sampai dengan paling banyak 50 milyar rupiah.

Keberlanjutan usaha bagi UMKM sangatlah penting, keberlanjutan usaha dapat dilihat dari berbagai faktor, di antaranya adalah faktor internal dan faktor eksternal suatu usaha. Dalam melihat keberlanjutan suatu usaha (Starik and Kanashiro, 2013) tidak satupun dari teori manajemen tentang keberlanjutan usaha memiliki fitur yang unik, memiliki manfaat, memiliki peluang, atau orientasi untuk membantu individu, organisasi, atau masyarakat untuk tetap bisa melanjutkan usahanya sebanyak dan secepat yang diperlukan sehingga faktor- faktor penentu keberlanjutan usaha bukanlah suatu hal yang baku berdasarkan teori tertentu.

\section{Pendapatan}

Menurut Hery (2013) dalam (Maulita et al, 2019), pendapatan merupakan aliran masukkan dari aktiva ataupun kenaikan aliran yang lain dari aktiva ataupun penyelesaian sesuatu kewajiban entitas ataupun campuran dari kedua aliran yang dimulai dari pengiriman benda, pemberian jasa, ataupun aktiva lain yang merupakan aktivitas pembedahan utama dari industri.

Menurut Karlina (2010) dalam (Riawan and Kusnawan, 2018) mengatakan bahwa penghasilan bisa dianggap menjadi suatu pendapatan usaha bila penghasilan yang diperoleh dari aktivitas operasional yang normal maupun aktivats di luar normal pada suatu industri atau usaha. Sedangkan yang dimaksud dengan pendapatan ialah pemasukan yang bersumber dari kegiatan industry dalam melaksanakan operasional semacam penjualan royalty deviden serta lain sebagainya.

\section{Pinjaman Usaha (Kredit)}

Dalam Undang-Undang Republik Indonesia nomor 10 tahun 1998 pasal 1 ayat 11 , yang dimaksud dengan kredit adalah penyediaan uang atau tagihan yang dapat dipersamakan dengan itu, berdasarkan persetujuan atau kesepakatan pinjam-meminjam antara bank dengan pihak lain yang mewajibkan pihak peminjam untuk melunasi utangnya setelah jangka waktu tertentu dengan pemberian bunga (Kemenkeu RI, 1998).

Menurut Kasmir (2013) dalam (Riawan and Kusnawan, 2018) kredit merupakan pembagian modal oleh bank dengan melakukan perjanjian pengembalian uang yang dipinjamkan atau dalam bentuk bagi hasil dengan jangka waktu yang disepakati bersama 
oleh para pihak penerima dan pemberi modal.

\section{Bantuan Pemerintah Untuk Usaha Mikro (BPUM)}

Demi mendukung bergulirnya kehidupan UMKM, pemerintah Indonesia membuat suatu program bantuan yang diberi nama Bantuan Pemerintah Untuk Usaha Mikro (BPUM) (Indonesia, 2020) kepada pelaku UMKM. Bantuan dari pemerintah tersebut, diharapkan mampu menyemangati para pelaku UMKM untuk tetap bertahan dan tetap dapat melanjutkan usaha yang telah di rintis di tengah resesi yang terjadi di Indonesia saat ini. BPUM yang diberikan oleh pemerintah Indonesia adalah sebesar Rp. 2.400.000,00. BPUM ini bisa di dapatkan oleh para pelaku UMKM dengan syaratsyarat sebagai berikut : WNI, memiliki NIK, bagi pemilik usaha yang mempunyai alamat KTP serta domisili usaha yang berbeda dapat melampirkan SKU, saat ini tidak sedang menerima kredit dari perbankan atau kredit usaha rakyat (KUR), kepemilikan usaha dibuktikan dengan surat yang berupa usulan calon penerima BPUM yang dibuat oleh pengusul BPUM, penerima bantuan BPUM bukan merupakan aparatur sipil negeri, bukan merupakan anggota TNI, bukan merupakan anggota Kepolisian RI, bukan merupakan pegawai BUMN ataupun pegawai BUMD.

\section{Covid-19}

Covid-19 merupakan singkatan dari Corona Virus Disease 2019, sejenis penyakit menular yang menginfeksi saluran pernafasan atas dan disebabkan oleh SARS-Cov-2 yang merupakan bagian dari jenis korona virus.

Infeksi virus Covid-19 ini terjadi akibat percikan droplet saat penderita mengalami batuk atau bersin. Gejala yang dialami oleh penderita virus covid-
19 dapat berupa demam, sulit bernapas, dan tenggorokan terasa kering.

Virus Covid-19 ini menyebabkan pandemi tidak hanya berdampak pada industri global, ataupun industri besar yang ada di Indonesia, pandemi COVID19 ini juga memiliki dampak yang besar terhadap Usaha Mikro Kecil Menengah (UMKM) di Indonesia.

\section{METODE PENELITIAN}

Data yang dikumpulkan pada penelitian ini merupakan data primer yang dihimpun dari survei on line dengan menggunakan kuisioner Google formulir. Penelitian tidak dilakukan dengan melakukan wawancara secara langsung terhadap responden disebabkan adanya pandemi yang mengharuskan setiap orang berusaha meminimalisir pertemuan dan menjaga jarak dengan orang lain. Pertanyaan yang diajukan pada kuisioner Google formulir merupakan pertanyaanpertanyaan yang spesifik berkaitan dengan pertanyaan mengenai keadaan usaha pelaku UMKM sebelum dan sesudah COVID-19. Para responden memahami dan mengerti bahwa jawaban yang mereka berikan akan dipublikasikan secara keseluruhan pada jurnal ilmiah.

Berdasarkan data yang berhasil dikumpulkan dari 32 (tiga puluh dua) responden yang berasal dari tujuh provinsi di Indonesia yang terdiri dari provinsi Banten, provinsi DKI Jakarta, provinsi Jawa Barat, provinsi Jawa Timur, provinsi DI Yogyakarta, provinsi Bali, provinsi Sumatera Selatan. Terdapat tujuh unit usaha dari pelaku UMKM yang ikut berpartisipasi dalam memberikan jawaban pada kuisioner. Ketujuh unit usaha tersebut adalah unit usaha makanan $40.6 \%$, unit usaha mode (pakaian, tas, sepatu) $21.9 \%$, unit usaha herbal $6.25 \%$, unit usaha perlengkapan hobi $9.38 \%$, unit usaha otomotif $3.13 \%$, unit usaha lainnya $13.8 \%$. Berdasarkan data yang dihimpun, $62.5 \%$ (20 responden) dari pelaku 
UMKM merupakan wanita sedangkan sisanya sebesar $37.5 \%$ (12 responden) merupakan laki laki. Rentang usia responden berada pada usia 20 sampai dengan 50 tahun ke atas.

Metode penelitian yang digunakan dalam penelitian ini adalah metode analisis regresi linier berganda. Data yang digunakan merupakan hasil survei yang dilakukan pada kelompok pelaku Usaha Mikro Kecil Menengah (UMKM) yang berada di Indonesia dengan sebaran wilayah pulau Jawa, pulau Bali dan pulau Sumatera yang merasakan dampak dari pandemi COVID-19 terhadap usaha yang UMKM jalankan.

\section{HASIL PENELITIAN DAN PEMBAHASAN}

\section{Hasil Penelitian}

\section{Hasil Uji Asumsi}

Berikut ini adalah hasil uji asumsi regresi klasik untuk melihat apakah terindikasi heteroskedastisitas dan multikolinieritas dalam model penelitian.

\section{Uji Heteroskedastisitas}

Uji Heteroskedastisitas dilakukan dengan menggunakan uji Glejser untuk melihat apakah terdapat masalah heteroskedastisitas dalam model yang digunakan. Hasil uji heteroskedastisitas dengan menggunakan metode Glejser menunjukan bahwa nilai antara variabel independen dengan absolut residual adalah sebagai berikut: hasil Prob ChiSquare (3) adalah 0.0731 yang memiliki nilai lebih besar dari $0.05(0.0731>0.05)$ maka dapat diartikan tidak terjadi gejala heteroskedastisitas pada model regresi ini.

\section{Uji Multikolinieritas}

Hasil uji multikolinieritas yang telah dilakukan maka didapat nilai centered VIF dari masing-masing variabel independen yaitu variabel pendapatan UMKM sebelum COVID-19 sebesar 1.020953, variabel pinjaman usaha/kredit sebesar 1.050733, dan variabel BPUM sebesar 1.05316. Nilai centered VIF dari masing-masing variabel independen $<10$ menunjukkan bahwa tidak terjadi multikolinieritas pada model yang diprediksi.

\section{Analisis regresi linier berganda}

Tabel 1: Hasil Uji Analisis Regresi Berganda

\begin{tabular}{lcccc}
\hline \multicolumn{1}{c}{ Variabel } & $\begin{array}{c}\text { Adjusted } \\
\mathbf{R}^{\mathbf{2}}\end{array}$ & Konstanta & $\begin{array}{c}\text { Koefisien } \\
\text { Regresi }\end{array}$ & t hitung \\
\hline Pendapatan UMKM & & & $0,4484^{*}$ & 3,3891 \\
seblum Covid 19 & & & & \\
Pinjaman Usaha & 0,3899 & $-0,3472$ & $0,6360^{*}$ & 2,9816 \\
Bantuan Pemerintah & & & $0,1082^{*}$ & 0,4519 \\
Usaha Mikro & & & & \\
\hline Nilai F hitung & & & & \\
\hline Keterangan: ${ }^{*}=\boldsymbol{\alpha}=\mathbf{0 , 0 1}$ & & & &
\end{tabular}

\section{Uji Koefisien Determinasi (Adjusted $\mathbf{R}^{2}$ )}

Berdasarkan nilai koefisien determinasi yang disesuaikan (adjusted $R$-squared) yaitu sebesar 0.3899, kontribusi pendapatan UMKM sebelum
Covid 19, pinjaman usaha, dan bantuan pemerintah usaha mikro (BPUM) kepada pendapatan UMKM pada masa pandemi Covid 19 sebesar 38,99\%, sedangakan sisanya sebesar $61,01 \%$ disumbangkan faktor lainnya yang tidak diteliti. 
Berikut ini adalah persamaan regresi linier berganda berdasarkan hasil output penelitian:

$$
\begin{gathered}
\mathrm{Y}=-0.3472+\left(0.4484 * \mathrm{X}_{1}\right)+\left(0.6360 * \mathrm{X}_{2}\right) \\
+\left(0.1082 * \mathrm{X}_{3}\right)
\end{gathered}
$$

Nilai koefisien pendapatan UMKM sebelum Covid 19 sebesar 0,4484 dengan asumsi mengabaikan variabel bebas lainnya menunjukkan bahwa pendapatan UMKM sebelum Covid 19 memiliki pengaruh positif terhadap pendapatan UMKM pada masa pandemi Covid 19, sehingga bila pendapatan sebelum Covid 19 meningkat sebesar 1\% maka akan mampu meningkatkan pendapatan pada masa pandemi Covid 19 sebesar $0.4484 \%$. Nilai koefisien positif pinjaman usaha/kedit sebesar 0.6360 , diasumsikan dengan mengabaikan variabel bebas lainya menunjukkan bahwa pinjaman usaha/kredit memiliki pengaruh positif terhadap pendapatan pada masa pandemi Covid 19 sehingga bila pinjaman usaha/kredit meningkat sebesar $1 \%$ maka mampu meningkatkan pendapatan pada masa pandemi Covid 19 sebesar 0.6360\%. Nilai koefisien positif BPUM sebesar 0.1082, diasumsikan dengan mengabaikan variabel bebas lainya menunjukkan bahwa BPUM memiliki pengaruh positif terhadap pendapatan pada masa pandemi Covid 19 sehingga bila BPUM meningkat sebesar $1 \%$ maka akan mampu meningkatkan pendapatan pada masa pandemi Covid 19 sebesar $0.1082 \%$.

Nilai $F$ hitung yang diperoleh adalah sebesar $0.0000791<0.005$, artinya pendapatan UMKM sebelum Covid 19, pinjaman usaha dan BPUM memiliki pengaruh yang signifikan secara bersama-sama terhadap pendapatan UMKM pada masa pandemi Covid 19 .

\section{Pembahasan}

Pendapatan sebelum Covid 19, pinjaman usaha, dan BPUM mendukung secara bersama sama terhadap pendapatan UMKM pada masa pandemi Covid 19. Hal ini dapat diinterpretasikan bahwa faktor-faktor tersebut merupakan usaha yang dilakukan oleh UMKM untuk mendapatkan pendapatan selama masa pandemi Covid 19. Pengusaha UMKM menggunakan pendapatan sebelum masa pandemi untuk dapat mempertahankan pendapatannya, juga pengusaha menggunakan pinjaman usaha dan bantuan pemerintah berupa BPUM agar dapat mempertahankan pendapatan selama masa pandemi Covid 19.

Pendapatan UMKM sebelum Covid 19yang dibandingkan dengan pendapatan UMKM pada masa Covid 19mengalami penurunan. Hal ini merupakan dampak dari peraturan-peraturan yang harus diterapkan selama masa pandemi, baik itu peraturan yang berlaku secara internasional berupa lockdown maupun peraturan yang berlaku secara nasional berupa PSBB. Peraturan-peraturan tersebut mengharuskan rakyat melakukan aktivitas di rumah saja, hanya keluar rumah bila ada suatu hal yang penting membuat roda perekonomian tidak laju berputar dan secara otomatis menurunkan pendapatan UMKM pada masa pandemi. Hal ini selaras dengan hasil analisis bahwa pendapatan UMKM sebelum Covid 19memiliki pengaruh signifikan terhadap pendapatan UMKM pada masa Covid 19.

Banyak dari pelaku usaha yang memiliki pinjaman usaha, pada saat terjadinya pandemi seperti ini pinjaman usaha sangat memberatkan bagi para pelaku UMKM. Banyak dari para pelaku usaha yang tetap harus membayarkan cicilan pinjaman usahanya sehingga mengurangi modal yang dimiliki oleh para pelaku usaha. Pengurangan modal tersebut pada akhirnya mengurangi 
pendapatan pada masa pandemi Covid 19. Hal ini selaras dengan hasil analisis bahwa peningkatan pinjaman usaha mendukung peningkatan pendapatan UMKM pada masa Covid 19.

Banyak dari para pelaku usaha yang tidak menerima BPUM, hal ini disebabkan karena kurangnya sosialisasi dari pemerintah untuk pencairan BPUM. Selain itu, kriteria yang ditetapkan oleh pemerintah utuk pencairan BPUM sangat sempit seperti pelaku usaha yang dapat menerima BPUM adalah pelaku usaha yang tidak memiliki pinjaman usaha (KUR), sedangkan banyak pelaku usaha kecil yang memiliki pinjaman usaha dan digunakan sebagai modal untuk usahanya. Dengan demikian hasil analisis ini sesuai dengan hipotesis bahwa peningkatan BPUM tidak mendukung peningkatan pendapatan UMKM pada masa Covid 19. Penelitian ini sejalan dengan penelitian yang dilakukan oleh (Hardilawati, 2020), bahwa pandemi Covid 19 sangat berpengaruh pada pendapatan UMKM.

\section{KESIMPULAN DAN SARAN}

\section{Kesimpulan}

Pendapatan sebelum Covid 19 dan pinjaman usaha mendukung peningkatan pendapatan saat terjadi pandemi Covid 19, namun hal ini tidak berlaku pada BPUM yang tidak mendukung peningkatan pendapatan saat terjadinya pandemi Covid-19. Dampak serius yang ditimbukan akibat pandemi Covid 19 terhadap pendapatan sangat memprihatinkan, namun UMKM di Indonesia masih mampu bertahan. Akan tetapi, walau mampu bertahan pada kondisi pandemi saat ini, UMKM sangat rentan kestabilan usahanya dengan pendapatan yang terus menerus mengalami penurunan, terutama bila masa pandemi berlanjut pada waktu yang cukup lama.

\section{Saran}

Dengan melihat hasil analisis dan kesimpulan, maka dapat disarankan halhal berikut: 1) Pelaku usaha perlu lebih dinamis dalam membuat suatu keputusan usaha, sehingga mampu menyesuaikan diri pada keadaan yang sulit terjadi pada dunia usaha dimasa yang akan datang. 2) Perhatian lebih dari pemerintah diharapkan karena UMKM memberikan kontribusi yang besar terhadap penyerapan tenaga kerja dan keberlangsungan ekonomi di Indonesia. Sosialisasi mengenai BPUM juga perlu lebih disebarluaskan kepada masyarakat, dengan jangka waktu sosialisasi yang lebih panjang agar lebih memiliki pengaruh dan membantu kondisi UMKM. Agar betul-betul dirasakan manfaatnya oleh para pelaku UMKM di Indonesia, pemerintah perlu meninjau kembali kriteria penerima BPUM. Kriteria yang sempit bagi penerima BPUM, menyebabkan tidak semua pelaku usaha mikro bisa mendapatkan bantuan tersebut. 3) Bagi peneliti yang akan melakukan penelitian mengenai pengaruh pandemi Covid 19 pada UMKM dapat dilakukan dengan jumlah responden yang lebih banyak, variabel yang berbeda, dan lebih bervariasi dari segi klasifikasi usahanya.

\section{DAFTAR PUSTAKA}

\section{Alam, S. 2020. Dua Ilmuwan Sebut COVID-19 Muncul Pertama Kali pada 2012. Available at: https://health.detik.com/berita- detikhealth/d-5137179/dua- ilmuwan-sebut-covid-19-muncul- pertama-kali-pada-2012.}

BPS. 2020a. Ekonomi Indonesia 2019 Tumbuh 5,02 Persen. Available at: https://www.bps.go.id/pressrelease/ 2020/02/05/1755/ekonomiindonesia-2019-tumbuh-5-02persen.html. 
BPS. 2020b Ekonomi Indonesia 2020 Turun sebesar 2,07 Persen (c-to-c). Available at: https://www.bps.go.id/pressrelease/ 2021/02/05/1811/ekonomiindonesia-2020-turun-sebesar-2-07persen--c-to-c-.html.

Hardilawati, W. L. 2020. 'Strategi Bertahan UMKM di Tengah Pandemi Covid-19', Jurnal Akuntansi \& Ekonomika, 10(1). Available at: https://ejurnal.umri.ac.id/index.php/ jae/article/view/1934/1223.

Indonesia, P. I. 2020. Cara Dapatkan Bantuan Pemerintah untuk UKM. Available at: https://indonesia.go.id/kategori/keu angan/2062/cara-dapatkan-bantuanpemerintah-untuk-ukm.

Kasim, et al. 2020. 'COVID-19 Impact on Business Sustainability: A Case of Micro-Small and Medium Enterprises in Malaysia', Journal of Humanities and Social Sciences Research, 2((S)), pp. 9-14. doi: 10.37534/bp.jhssr.2020.v2.ns.id103 5.p9.

Kemenkeu RI. 1998. UNDANGUNDANG REPUBLIK INDONESIA NOMOR 10 TAHUN 1998 TENTANG PERBANKAN. Available at: https://jdih.kemenkeu.go.id/fullTex t/1998/10Tahun 1998UU.htm.

Kemenkop UKM RI. 2020. Perkembangan Data Usaha Mikro, Kecil, Menengah (UMKM) dan Usaha Besar (UB) Tahun 2017 2018. Available at: http://www.depkop.go.id/uploads/la poran/1580223129_PERKEMBAN GAN DATA USAHA MIKRO, KECIL， MENENGAH (UMKM) DAN USAHA BESAR (UB) TAHUN 2017 - 2018.pdf.
Maulita et al. 2019. 'ANALISIS PENGARUH BEBAN USAHA DAN PENDAPATAN USAHA TERHADAP LABA PERUSAHAAN PADA PT. ARPENI PRATAMA OCEAN LINE Tbk.' Available at: https://www.jurnal.wicida.ac.id/ind ex.php/sebatik/article/view/778.

OJK. 2008. Undang-Undang Republik Indonesia No. 20 Tahun 2008 Tentang Usaha Mikro, kecil dan Menengah, 2008.

Pranita, E. 2020. Diumumkan Awal Maret, Ahli: Virus Corona Masuk Indonesia dari Januari. Available at:

https://www.kompas.com/sains/rea d/2020/05/11/130600623/diumumk an-awal-maret-ahli--virus-coronamasuk-indonesia-dari-januari.

Riawan and Kusnawan, W. 2018. 'Pengaruh Modal Sendiri Dan Kredit Usaha Rakyat (KUR) terhadap Pendapatan Usaha (Studi Pada UMKM di Desa Platihan Kidul Kec. Siman)', Jurnal Akuntansi dan Pajak, 19(01), pp. 31-37. Available at: https://jurnal.stie-

aas.ac.id/index.php/jap/article/view /158/pdf.

S. Lidya Julita. 2020. Sri Mulyani Bicara Dampak PSBB: Luar Biasa Serius! Available at: https://www.cnbcindonesia.com/ne ws/20200911180024-4-186241/srimulyani-bicara-dampak-psbb-luarbiasa-serius.

Starik, M. and Kanashiro, P. 2013. 'Toward a Theory of Sustainability Management: Uncovering and Integrating the Nearly Obvious', Organization and Environment, 26(1), pp. 7-30. doi: $10.1177 / 1086026612474958$. 